the CSF of normal children, $69 \%$ of whom were aged under 3 years; IgG ranged from 0.1 to 3.6 $\mathrm{mg} / 100 \mathrm{ml}$ with a mean IgG level of $0.84 \mathrm{mg} / 100 \mathrm{ml}$. In the 10 children with viral meningitis, IgM was undetectable in 9 children and present in a concentration of $1.6 \mathrm{mg} / 100 \mathrm{ml}$ in one child; IgM was undetectable in 2 children with bacterial meningitis, and in the remainder it ranged from 0.75 to $5 \cdot 1$ $\mathrm{mg} / 100 \mathrm{ml}$ (mean 2.64). IgG levels were raised in excess of $5 \mathrm{mg} / 100 \mathrm{ml}$ in 7 of 9 children with bacterial meningitis. The mean levels of all CSF immunoglobulins, particularly IgG, were significantly higher in bacterial than in viral meningitis (Table 2).

\section{Discussion}

It is known that serum immunoglobulins are lower in children than in adults. At age 1-2 years serum IgG, $\operatorname{IgM}$, and IgA are 66,59 , and $25 \%$ of respective adult values (Stiehm and Fudenberg, 1966). It is believed that CSF immunoglobulins are derived by

Table 2 Significance in the differences (mean $\pm S D$ ) in distribution of CSF substances in three groups of children using the Mann-Whitney $U$ test

\begin{tabular}{llll}
\hline CSF & $\begin{array}{l}\text { Normal } v . \\
\text { viral }\end{array}$ & $\begin{array}{l}\text { Normal } v . \\
\text { bacterial }\end{array}$ & $\begin{array}{l}\text { Viral } v . \\
\text { bacterial }\end{array}$ \\
\hline Protein & $\mathrm{P}<0.01$ & $\mathbf{P}<0.01$ & $\mathbf{P}<0.01$ \\
Glucose & NS & $\mathbf{P}<0.01$ & $\mathbf{P}<0.01$ \\
IgA & NS & $\mathbf{P}<0.01$ & $\mathbf{P}<0.05$ \\
IgM & NS & $\mathbf{P}<0.01$ & $\mathbf{P}<0.01$ \\
IgG & $\mathrm{P}<0.05$ & $\mathrm{P}<0.01$ & $\mathrm{P}<0.05$ \\
\hline
\end{tabular}

diffusion from serum, although the lymphoid tissue may produce IgG (Lord et al., 1973).

In the present study a statistically significant difference in CSF IgG levels was shown between normal children and those with viral or bacterial meningitis, although the levels overlapped. High levels of CSF IgG ( $>5 \mathrm{mg} / 100 \mathrm{ml})$ were found in 7 children, and high levels of $\operatorname{IgM}(>3 \mathrm{mg} / 100 \mathrm{ml})$ in 5 of 9 children with bacterial meningitis.

Retrospectively, CSF immunoglobulins did not enhance the diagnostic accuracy of acute childhood meningitis as similar information could be gained from study of the total differential white cell count in combination with protein and glucose analyses (Table 1).

\section{References}

Lord, R. A., Dupree, E., Goldblum, R. M., Stacy, W. D., Forman, F. M., and Goldman, A. S. (1973). Cerebrospinalfluid IgM in the absence of serum IgM in combined immunodeficiency. Lancet, 2, 528-529.

Mancini, G., Carbonera, A. O., and Heremans, J. F. (1965). Immunochemical quantitation of antigen by single radial immunodiffusion. International Journal of Immunochemistry, 2, 235-254.

Smith, H., Bannister, B., and O'Shea, M. J. (1973). Cerebrospinal fluid immunoglobulins in meningitis. Lancet, 2, 591-593.

Stiehm, E. R., and Fudenberg, H. H. (1966). Serum levels of immune globulins in health and disease. Pediatrics, 37, 715-727.

Correspondence to Dr Denis Gill, Children's Hospital, Temple Street, Dublin 1, Eiré.

\title{
Treatment of a neonate with propionic acidaemia and severe hyperammonaemia by peritoneal dialysis
}

\author{
M. F. ROBERT, D. J. SCHULTZ, B. WOLF, W. D. COCHRAN, AND A. L. SCHWARTZ \\ Department of Medicine, Children's Hospital Medical Center, Boston, and Department of Human \\ Genetics and Pediatrics, Yale University, New Haven, USA
}

SUMMARY A moribund newborn infant with propionic acidaemia and severe hyperammonaemia was successfully treated by peritoneal dialysis. The removal of ammonia and possibly additional toxic metabolites by peritoneal dialysis may be life-saving in newborn infants with propionic acidaemia or other hyperammonaemic syndromes.

Propionic acidaemia is a rare inborn error of metabolism which can be present in the neonatal period with persistent ketoacidosis and altered neurological status (Rosenberg, 1978). Survival of an infant thus affected depends on rapid diagnosis and immediate institution of measures to alleviate the chemical imbalances accompanying the disease. The usual treatment is to restrict the proteins while maintaining adequate calories and fluids to prevent the accumulation of harmful metabolites, but occasionally deterioration of the condition of the patient necessitates more drastic removal of these metabolites. We report a case of a neonate with propionic acidaemia who had extremely high blood ammonia concentrations with coma, but who survived after the rapid removal of ammonia by peritoneal dialysis. 


\section{Case report}

A 3-kg baby girl, born at term after an uncomplicated pregnancy to a 27 -year-old mother, was the only child of nonconsanguineous parents. She did well initially and was breast fed for the first days of life. Tachypnoea $(>80 / \mathrm{min})$ was noted on the second day of life (Figure) and hepatomegaly on the third, when the baby was transferred to Boston Children's Hospital Medical Center.

On admission (day 3), arterial blood-gases showed a metabolic acidosis with a compensatory respiratory alkalosis-pH 7.30, $\mathrm{Po}_{2} 110 \mathrm{mmHg}(14.6 \mathrm{kPa})$, $\mathrm{PCO}_{2} 12 \mathrm{mmHg}(1 \cdot 6 \mathrm{kPa})$, total $\mathrm{CO}_{2} 6 \mathrm{mmol} / 1$. White blood celland platelet counts were normal. Chest $x$-ray was normal. Serum electrolytes were $\mathrm{Na} 144, \mathrm{~K} 4$, and $\mathrm{C1} 103 \mathrm{mmol} / \mathrm{l}$, resulting in an anion gap of $39 \mathrm{mmol} / \mathrm{l}$, indicating severe metabolic acidosis. The baby had protracted hypoglycaemia which required dextrose infusion, initially at $6 \mathrm{mg} / \mathrm{kg}$ per $\mathrm{min}$, to maintain a blood glucose concentration of 100-200 $\mathrm{mg} / 100 \mathrm{ml}(5 \cdot 5-11 \mathrm{mmol} / \mathrm{l})$. When the dextrose infusion was stopped there was a fall in blood glucose within 30 minutes to $27-36 \mathrm{mg} / 100 \mathrm{ml}(1 \cdot 5-2 \cdot 0$ $\mathrm{mmol} / \mathrm{l})$, a level which persisted for more than 2 hours. Thereafter, dextrose infusion at $8 \mathrm{mg} / \mathrm{kg}$ per min was required to maintain normoglycaemia. Additional studies included a urine dinitrophenylhydrazine test which was positive for $\alpha$-keto acids and urine, and plasma amino-acid profiles which were within normal limits. Plasma glycine was 432 $\mathrm{mmol} / 1$ (normal, $120-560 \mathrm{mmol} / \mathrm{l}$ ).

On day 4, the baby was flaccid and had sustained ankle clonus. There was no evidence of infection. Because of this change in her previously normal neurological status and the evidence of a metabolic disorder, blood ammonia was determined and was noted to be high at $150 \mu \mathrm{g} / 100 \mathrm{ml} ; 83 \mu \mathrm{mol} / \mathrm{l}$ (normal, less than $50 \mu \mathrm{g} / 100 \mathrm{ml} ; 28 \mu \mathrm{mol} / \mathrm{l}$ ). On day 5 , her blood ammonia level rose to $350 \mu \mathrm{g} / 100 \mathrm{ml}$ $(194 \mu \mathrm{mol} / \mathrm{l})$. She became stuporous in spite of vigorous hydration and adequate caloric administration with dextrose. Attempts to perform an exchange transfusion were unsuccessful.

Therefore, peritoneal dialysis was started, cycling $150 \mathrm{ml}$ each hour with an intra-abdominal dwell time of 30 minutes (dialysis solution per litre: $\mathrm{Na} \mathrm{132,} \mathrm{C1}$ $102, \mathrm{~K} 3 \cdot 5, \mathrm{Ca} 10, \mathrm{Mg} 1 \cdot 5, \mathrm{HCO}_{3} 25 \mathrm{mmol} / 1$, dextrose $15 \mathrm{~g}, \mathrm{pH} 6 \cdot 8$ ). During the 8th cycle, the respiration arrested and was subsequently maintained by assisted ventilation for approximately 27 hours. At the time of her respiratory arrest, the baby was in coma, with fixed dilated pupils, no spontaneous respirations, and absent reflexes. Blood ammonia shortly after the arrest was $1350 \mu \mathrm{g} / 100 \mathrm{ml}(748$ $\mu \mathrm{mol} / \mathrm{l})$. EEG was consistent with severe toxic encephalopathy.

Despite the baby's condition, dialysis was continued. Subsequent measurements of blood ammonia before and after a dialysis cycle showed a decrease of approximately $100 \mu \mathrm{g} / 100 \mathrm{ml}(55 \mu \mathrm{mol} / \mathrm{l})$ during the cycle. At 15 hours, she was no longer acidotic. She then began to move spontaneously, and there was gradual neurological improvement. After 30 dialysis cycles (late on day 6), ammonia level was 150 $\mu \mathrm{g} / 100 \mathrm{ml}(83 \mu \mathrm{mol} / \mathrm{l})$ and dialysis was stopped. She breathed spontaneously and had reactive pupils. She was extubated on the morning of day 7.

On the 8th day, she was started on a low protein diet, $100 \mathrm{kcal} / \mathrm{kg}(0.5 \mathrm{~g} / \mathrm{kg}$ per day $)$ with $50 \%$ of her calories as even short-chain triglycerides. Results of gas-liquid chromatography and mass spectrometry* of the urine showed the presence of 3-hydroxypropionic acid, methylcitrate, tiglylglycine, and *Performed by Dr C. Costello, Massachusetts Institute of Technology, and Dr K. Tanaka, Yale University.

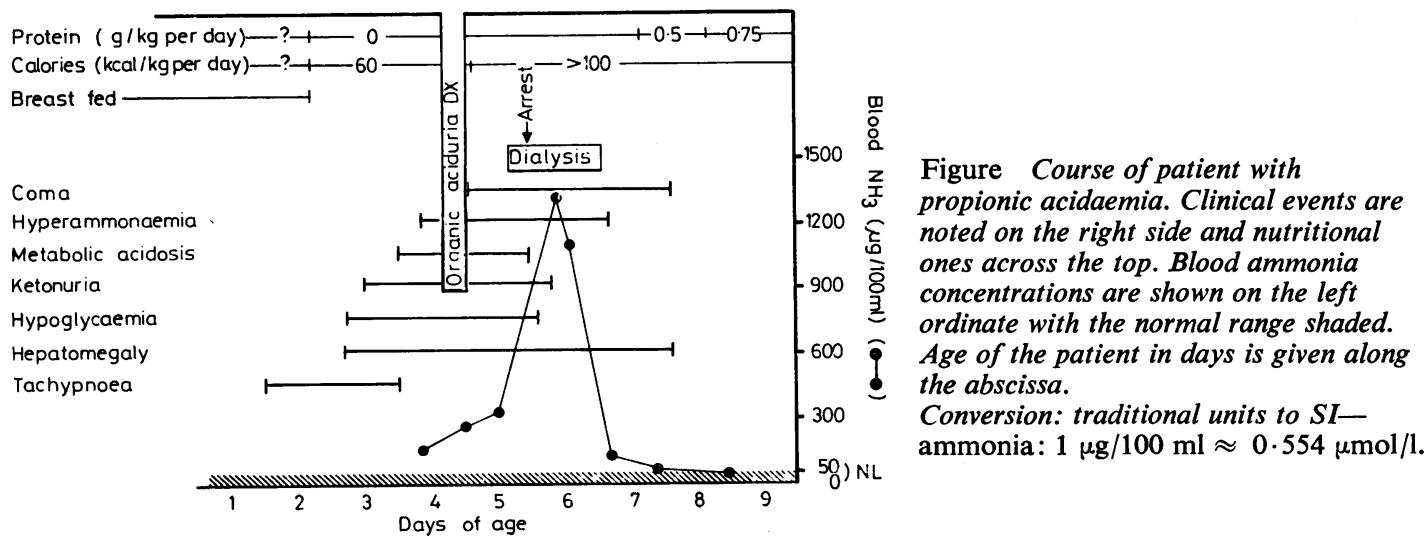

Figure Course of patient with propionic acidaemia. Clinical events are noted on the right side and nutritional ones across the top. Blood ammonia concentrations are shown on the left ordinate with the normal range shaded. Age of the patient in days is given along the abscissa. Conversion: traditional units to SIammonia: $1 \mu \mathrm{g} / 100 \mathrm{ml} \approx 0.554 \mu \mathrm{mol} / 1$. 
propionylglycine, findings appropriate to the diagnosis of propionic acidaemia. She was therefore empirically started on $5 \mathrm{mg}$ per day biotin orally, which was stopped when her defect was clearly defined by enzyme studies to be nonresponsive to biotin. She became increasingly alert, and was discharged from the hospital on day 12 . Her daily diet consisted of $0.95-1.0 \mathrm{~g}$ protein $/ \mathrm{kg}$ and 120 $\mathrm{kcal} / \mathbf{k g}$.

Since discharge, she has had several viral illnesses with associated metabolic acidosis, ketonuria, and a peak blood ammonia of $170 \mu \mathrm{g} / 100 \mathrm{ml}(94 \mu \mathrm{mol} / \mathrm{l})$; these have required parenteral treatment with fluids and a short time in hospital. Otherwise, she has remained in good metabolic control and has gained weight, being $6.6 \mathrm{~kg}$ at 15 months. Unfortunately, she developed an athetoid disorder during her second viral illness and her developmental milestones are delayed.

\section{Fibroblast and leucocyte enzyme analysis}

Propionyl CoA carboxylase (PCC) and $\beta$-methylcrotonyl CoA carboxylase ( $\beta-\mathrm{MCC})$ activities were measured in isolated peripheral leucocyte extracts and in skin fibroblast cultures established from the patient and her parents as previously described (Wolf and Rosenberg, 1978). As shown in the Table, the patient has deficient propionyl CoA carboxylase activity both in her fibroblast and leucocyte extracts. PCC activities in fibroblast and leucocyte extracts from both parents were intermediate between deficient and control values, whereas $\beta$-MCC activities in fibroblast extracts from the patient and her parents were normal. The patient's PCC was not stimulated by incubating her fibroblast cultures in medium containing $10 \mathrm{mg} / \mathrm{ml}$ biotin for 4 days. Fibroblasts from the patient were assigned to the $\mathrm{A}$ complementation group (Gravel et al., 1977).

Table Propionyl CoA carboxylase and $\beta$-methylcrotonyl CoA carboxylase activities (pmol/min per $\mathrm{mg}$ protein) in leucocyte and fibroblast extracts of patient and parents

\begin{tabular}{|c|c|c|c|}
\hline & \multirow{2}{*}{$\frac{\text { Leucocyte }}{\text { PCC activity* }}$} & \multicolumn{2}{|l|}{ Fibroblast } \\
\hline & & PCC activity & $\beta-M C C$ activity \\
\hline $\begin{array}{l}\text { Patient } \\
\text { Mother } \\
\text { Father } \\
\text { Controls }(n=8)\end{array}$ & $\begin{array}{l}4 \\
178 \\
210 \\
349 \pm 51^{*}\end{array}$ & $\begin{array}{l}17 \\
399 \\
559 \\
863 \pm 102^{*}\end{array}$ & $\begin{array}{l}297 \\
295 \\
340 \\
283 \pm 32^{*}\end{array}$ \\
\hline
\end{tabular}

*1 SD.

\section{Discussion}

The importance of rapid diagnosis of inborn errors of metabolism cannot be overemphasised. Our patient was 4 days old and semicomatose when hyper- ammonaemia was first noted. Persistent metabolic acidosis, ketonuria, and progressive deterioration in neurological status were all clues that the patient had a metabolic disorder. Tachypnoea, which developed during the period of breast-milk feeding, and hyperammonaemia pointed towards protein intolerance.

The presence of propionate metabolites in the urine suggested propionic acidaemia, the result of deficient activity of the enzyme propionyl CoA carboxylase that normally catabolises propionate to methylmalonate. The absence of raised propionate itself in the urine is probably due to its being metabolised via minor pathways and its conjugation with glycine, which is usually raised in the plasma and urine of patients with propionic acidaemia. The normal value of glycine in our patient was unusual and misleading. However, previous cases of propionic acidaemia with intermittently normal concentrations of glycine have been reported (Wadlington et al., 1975). Furthermore, although most patients with propionic acidaemia have normoglycaemia, occasionally a case may demonstrate slight hypoglycaemia (Rosenberg, 1978); our patient, however, exhibited severe hypoglycaemia. The mechanism causing decreased blood glucose is not known but may involve the inhibition of gluconeogenesis.

In addition to propionic acid and glycine, ammonia concentrations may be raised in the blood of patients with propionic acidaemia. Hyperammonaemia, as seen in urea cycle disorders, Reye's syndrome, or hepatic failure, and ketoacidosis, as seen in diabetes, most certainly contributed to our patient's comatose state. Propionate, which unfortunately was not measured in our patient, or its metabolites, may also have primary or secondary toxicity.

Instituting a low-protein diet, sufficient carbohydrates, and even-chain triglycerides is essential, and is usually sufficient to achieve a homeostatic metabolism in patients with propionic acidaemia (Brandt et al. 1974). Our patient's rapid and severe neurological deterioration required more drastic therapy, peritoneal dialysis, to remove the toxic agents, but the fact that dialysis for $\mathbf{3 0}$ hours was required to return the ammonia level to normal suggests that our patient continued to produce ammonia probably by catabolism of her own protein. We cannot, however, exclude the harmful effect of a respiratory arrest in increasing the blood ammonia concentration or the beneficial effect of assisted ventilation in reducing the blood ammonia concentration. Peritoneal dialysis was previously used by Russell $e t$ al. (1974) to remove propionate from a severely ill infant with propionic acidaemia, but the ammonia levels were not measured. Peritoneal diaylsis has 
been used unsuccessfully to treat the severe hyperammonaemia associated with a patient with ornithine transcarbamylase deficiency (Siegel and Brown, 1973). The peak level of ammonia recorded for our patient is the highest yet reported in a patient with propionic acidaemia. This case is presented as the first successful demonstration that peritoneal dialysis together with protein restriction, adequate hydration, and sufficient caloric intake can be life-saving in propionic acidaemia even after the affected newborn has become moribund.

Note added in proof. At age 20 months, the patient developed a viral gastroenteritis, severe metabolic acidosis, and died.

We thank Dr L. E. Rosenberg for help with this patient.

\section{References}

Brandt, I., Hsia, Y. E., Clement, D. H., and Provence, S. A. (1974). Propionicacidemia (ketotic hyperglycinemia): dietary treatment resulting in normal growth and development. Pediatrics, 53, 391-395.
Gravel, R. A., Lam, K. F., Scully, K. J., and Hsia, Y. E. (1977). Genetic complementation of propionyl CoA carboxylase deficiency in cultured human fibroblasts. American Journal of Human Genetics, 29, 378-388.

Rosenberg, L. E. (1978). Disorders of propionate, methylmalonate, and cobalamin metabolism. In The Metabolic Basis of Inherited Disease, fourth edition, pp. 411-429. Edited by J. B. Stanbury, J. B. Wyngaarden, and D. S. Fredrickson. McGraw-Hill: New York.

Russell, G., Thorn, H., Tarlow, M. J., and Gompertz, D. (1974). Letter: Reduction of plasma propionate by peritoneal dialysis. Pediatrics, 53, 281-283.

Siegel, N. J., and Brown, R. S. (1973). Peritoneal clearance of ammonia and creatinine in a neonate. Journal of Pediatrics, 82, 1044-1046.

Wadlington, W. B., Kilroy, A., Ando, T., Sweetman, L., and Nyhan, W. L. (1975). Hyperglycemia and propionyl CoA carboxylase deficiency and episodic severe illness without ketosis. Journal of Pediatrics, 86, 707-712.

Wolf, B., and Rosenberg, L. E. (1978). Heterzygote expression in propionyl coenzyme A carboxylase deficiency: differences between major complementation groups. Journal of Clinical Investigation, 62, 931-936.

Correspondence to Dr A. L. Schwartz, Department of Medicine, Children's Hospital Medical Center, 300 Longwood Avenue, Boston, Massachusetts 02115, USA.

\title{
Transient infantile hyperthyrotropinaemia
}

\author{
Report of a case
}

\section{KIYOSHI MIYAI, NOBUYUKI AMINO, KEIKO NISHI, TOMIKO FUJIE, KIYOMI NAKATANI, OSAMU NOSE, TOKUZO HARADA, HYAKUJI YABUUCHI, KEI DOI, TOSHIHIDE YAMAMOTO, RITSUKO SATAKE, TSUNEO TSURUHARA, AND TOSHIAKI OURA}

Central Laboratory for Clinical Investigation and Department of Paediatrics, Osaka University Medical School, Centre for Adult Diseases, St Barnabas's Hospital, and Children's Medical Centre of Osaka City, Japan

SUMMARY A case of transient hyperthyrotropinaemia was found by mass screening for neonatal hypothyroidism using the paired TSH assay method. The patient was a baby boy born at term after a normal pregnancy who grew without any abnormal signs or symptoms. For the first 7 months after birth, his serum TSH was abnormally high while his total serum T4, T3, and free T4, T3 were within normal limits, except for slightly low free T4 level at 7 months. The raised serum TSH decreased spontaneously to within normal limits after he was 9 months old.

With the recent development of techniques for testing thyroid activity, some interesting neonatal cases of thyroid dysfunction have been found. One of the most important developments in this field has been the introduction of mass screening for neonatal hypothyroidism, and several mass screening programmes have been reported. We have developed a new 'paired TSH assay method' (Miyai et al., 1978). We were able to screen 91400 babies between November 1975 and September 1978, and found 9 cases of primary hypothyroidism. We also found a boy who had high TSH but normal levels of thyroid hormones in the serum for 7 months, but whose TSH level decreased spontaneously to within normal limits after 9 months. This syndrome, which apparently differs from the transient neonatal hypothyroidism reported by La Franchi et al. (1977) and Delange et al. (1978), is described. 